\title{
Outcomes of cesarean scar pregnancy treatment: Do we have options?
}

\section{Sezaryen skar gebelik tedavisi: Seçeneklerimiz neler?}

\author{
(1) Seda Yüksel Şimşek, (1) Erhan Şimşek, (1) Didem Alkaş Yağınç, (1) Şafak Yılmaz Baran, (1) Tayfun Çok, \\ (D) Esra Bulgan Kılıçdağ
}

Başkent University Faculty of Medicine, Adana Dr. Turgut Noyan Research and Application Center, Clinic of Obstetrics and Gynecology, Adana, Turkey

\begin{abstract}
Objective: To investigate the success and complications of medical and surgical modalities used in the treatment of cesarean scar pregnancies. Materials and Methods: Medical and surgical approaches that have been used to treat cesarean scar pregnancies were evaluated retrospectively, Local, systemic, and combined methotrexate treatments were grouped as the medical approach, and dilatation and evacuation, hysteroscopic resection, laparoscopic and laparotomic approaches were grouped as the surgical approach. Fifty-three patients were diagnosed as having cesarean scar pregnancy during the study period, 48 of whom were included in the final analysis. Eighteen patients were treated with medical interventions and 30 patients were treated surgically. Results: The success rate of surgical modalities was $96.6 \%$ and the medical treatment success was $33 \%$ ( $<<0.001$ ). The complication rate was higher with medical approaches compared with surgical methods ( $66 \%$ vs $3.3 \%$, respectively; $<<0.001$ ).

Conclusion: Surgical intervention seems safer and more successful than medical treatment.

Keywords: Ectopic pregnancy, cesarean scar pregnancy, cesarean scar ectopic pregnancy

$\ddot{\mathrm{O} z}$

Amaç: Sezaryen skar gebeliklerin tedavisinde yararlanılan medikal ve cerrahi yöntemlerin etkinlik ve komplikasyonlarının incelenmesi amaçlanmıştır. Gereç ve Yöntemler: Sezaryen skar gebelik tanısı alan toplam 53 hastanın verisi retrospektif olarak incelenmiştir. Lokal, sistemik ve combine metotreksat medikal yaklaşım olarak sınıflandırılırken; dilatasyon evakuasyon, histereskopik rezeksiyon, laparoskopik ve laparotomik rezeksiyon cerrahi yaklaşım olarak sınıflandırılmıştır. Elli üç hastanın 48'inin verisi final analizde yer almıştır. On sekiz hasta medikal, otuz hasta ise cerrahi yaklaşım grubunda bulunmaktadır.

Bulgular: Cerrahi yaklaşım ile tedavi edilen hastalarda tedavi başarısı \%96,6 iken; medikal yöntemlerin kullanıldığı hastalarda tedavi başarısı \%33 olarak bulunmuştur $(\mathrm{p}<0,001)$. Komplikasyon oranları ise medikal ve cerrahi grupta sırası ile \%66 ve \%33 olarak belirlenmiştir ( $\mathrm{p}<0,001)$.

Sonuç: Sezaryen skar gebeliklerin tedavisinde cerrahi yöntemler medikal yaklaşımlara göre daha başarılı ve güvenlidir.

Anahtar Kelimeler: Ektopik gebelik, sezaryen skar gebelik, sezaryen skar ektopik gebelik
\end{abstract}

\section{Introduction}

The cesarean delivery rate has increased worldwide and complications related to cesarean sections have also increased correspondingly. In this context, cesarean scar pregnancy (CSP) is seen as one of the rare complications, which is described as the embedding of the conceptus into the myometrium under cesarean scar tissue. CSP is classified as a subtype of ectopic pregnancy; some authors object to this because most of the placental tissue is within the endometrial cavity ${ }^{(1)}$. Flystra( ${ }^{(2)}$ noted that there were about 19 cases at the beginning of this century and scar pregnancy was the rarest type of ectopic pregnancy ${ }^{(3)}$. Recently, the incidence of CSP has begun to increase with the increment of cesarean delivery rates and the prevailing use of high-resolution transvaginal ultrasonography (USG). Contemporary studies report the incidence rate as $1 / 1800-2000$, accounting for $6 \%$ of all ectopic pregnancies ${ }^{(1,4-6)}$. Early diagnosis and prompt treatment have paramount importance because there are high risks of severe hemorrhage, uterine rupture, and placental adhesion abnormalities ${ }^{(6)}$.

PRECIS: Surgical treatments are safe and effective in treatment of cesarean scar pregnancies. Although medical approaches are less invasive; need for second-line therapy is higher.

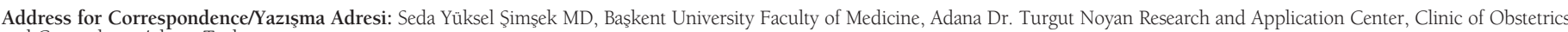
and Gynecology, Adana, Turkey

Phone: +90 5359112244 E-mail: dryukselseda@hotmail.com ORCID ID: orcid.org/0000-0003-3191-9776

Received/Geliș Tarihi: 12.04.2021 Accepted/Kabul Tarihi: 03.05.2021

${ }^{\circledR}$ Copyright 2021 by Turkish Society of Obstetrics and Gynecology

Turkish Journal of Obstetrics and Gynecology published by Galenos Publishing House. 
Vial et al. ${ }^{(7)}$ categorized CSPs regarding their growth pattern and connection to the uterine cavity and serosa. Type 1 scar pregnancies grow toward the cervico-isthmic area, whereas type 2 pregnancies tend to grow toward the bladder serosa. Type 2 scar pregnancies seem to be accompanied by uterine rupture more often at early gestational weeks and severe hemorrhage, whereas type 1 scar pregnancies have greater potential for continuation, but with the risk of severe placental adhesion abnormalities and postpartum hemorrhage, hysterectomy, and maternal morbidity and mortality ${ }^{(7)}$.

Risk factors of CSP are a high number of previous cesarean deliveries, uterine surgeries, cesarean delivery before labor onset, and pregnancy with artificial reproductive techniques ${ }^{(3,8)}$. The limited number of cases in the literature gave rise to insufficient data to constitute a standard treatment $\operatorname{protocol}^{(6)}$. The aim of this study was to investigate CSPs diagnosed and treated in a tertiary referral center, especially regarding treatment modalities.

\section{Materials and Methods}

Patients who were diagnosed as having CSP between December 2012 and July 2019 were included in this retrospective crosssectional observational study. The hospital record database was searched for all types of ectopic pregnancies and records were further examined for surgeries of CSPs.

Demographic features, medical histories, beta-human chorionic gonadotropin (beta-hCG) levels, route and time of prior deliveries, the indication of prior cesarean deliveries, treatment modalities, complications, and subsequent obstetric outcomes were obtained from the patient record database. A telephonebased search was also performed.

The following USG criteria were used for the diagnosis of CSP: (1) Absence of gestational sac, both in the uterine and cervical canal; (2) Presence of gestational sac in the anterior isthmic area and embedded in the hysterotomy scar; (3) Presence of fetal pole, whether the yolk sac and fetal cardiac activity are present or absent; (4) A present thin myometrial layer or no myometrial lining between the bladder and uterus; and (5) Discontinuity of the anterior uterine wall in the sagittal view. A diagnosis of CSP was made when all these criteria were observed.

Choice of treatment modality was made primarily depending on the patients' clinical features, USG findings, and desire for future fertility. Medical treatment modalities included local, systemic, and combined methotrexate administration. These modalities were preserved for patients who did not have heavy bleeding and were hemodynamically stable. Clinical features, which included contraindications for methotrexate such as active liver disease, were questioned, especially before methotrexate administration, and an effective contraception method was recommended after treatment because of the possible fetotoxicity of the drug. Surgical approaches were performed in the event of heavy vaginal bleeding that required prompt medical attention and in patients who failed to respond to medical treatment.
All available treatment options were explained in detail to all patients, except in emergency cases for which a surgical attempt was required. Patients were informed about the possible adverse effects of the medication, risk of heavy bleeding during follow-up, need for emergency hysterectomy, failure rates of treatments, and the risk of placental adherence abnormalities in the event of continuation of pregnancy in light of the literature. After this briefing, the treatment modality was determined with the consensus of the physician and the patient. Informed consent forms were signed by all patients.

The cytotoxic effect of methotrexate on trophoblastic cells is the common mechanism of action for systemic, local, and combined methotrexate therapy, thus they are grouped as the medical approach. These modalities also do not require a major invasive procedure. Dilatation curettage, and hysteroscopic, laparoscopic, and laparotomic resections are grouped as surgical approaches because they all necessitate surgically invasive procedures and require mechanical removal of the ectopic mass.

\section{Intervention}

Systemic methotrexate: A single-dose regimen with a $50 \mathrm{mg} /$ $\mathrm{m}^{2}$ intramuscular injection. Four and 7 days after the injection, beta-hCG levels, complete blood count, and liver function tests were measured. A beta-hCG decrement less than 15\% between days 4 and 7 was regarded as treatment failure.

Local methotrexate: The required dose was calculated as 50 $\mathrm{mg} / \mathrm{m}^{2}$. While the patient was in the lithotomy position, after disinfection of the vagina with $10 \%$ povidone-iodine, a doublelumen oocyte pick-up needle was inserted vaginally and the gestational sac was disrupted, and the content was aspirated as much as possible. Half of the calculated dose was injected into the sac and the remaining dose was injected into the periphery of the gestational sac. During all these processes, transabdominal USG imaging (Logiq Alpha 200 Ultrasound, General Electric Medical Systems) was used for guidance. Local methotrexate at a dose of $50 \mathrm{mg} / \mathrm{m}^{2}$ was administered. In the event of a betahCG level decrement less than 25\% 7 days after the injection, a systemic rescue dose $\left(50 \mathrm{mg} / \mathrm{m}^{2}\right)$ of methotrexate was added. The requirement for rescue systemic methotrexate was also recorded as a treatment failure.

Combined methotrexate: Local and systemic administration of $50 \mathrm{mg} / \mathrm{m}^{2}$. Local administration and systemic injections were given at the same time. Beta-hCG levels were measured weekly. Outpatient follow-up was preferred for medically treated patients as long as they were clinically stable. Patients were informed and warned to present to the emergency department in the event of symptoms such as severe abdominal pain, hypotensive attacks, and massive vaginal bleeding. Weekly transvaginal USG was also performed to follow the resorption of the ectopic mass. Beta-hCG levels, renal and liver function tests were performed to check for the possible adverse effects of methotrexate every week during the follow-up. 
USG-guided dilatation-evacuation (D\&E): This procedure was conducted in an operating room with the patient under sedation. Number 5 and 6 Carmen aspiration cannulas were used to evacuate the gestational content. Transabdominal USG guidance was used to visualize the uterus.

Hysteroscopic resection: A hysteroscopic resectoscope was used to remove gestational content, and bipolar cautery was used to control the bleeding areas.

Laparoscopic resection: The CSP area was cut using harmonic bipolar cautery and removed and the myometrial defect was sutured using non-absorbable interrupted sutures.

Laparotomic resection: A Pfannenstiel incision was made to reach the abdominal cavity. Gestational content and cesarean scar tissue were resected, and myometrial defects were repaired using interrupted absorbable sutures.

Expectant management: Patients with positive fetal cardiac activity who desired to continue the pregnancy opted for expectant management. The high risk of placental adherence abnormalities, severe life-threatening bleeding, and the need for emergency hysterectomy was fully explained. Close followup in a tertiary referral center with the facility for high-risk pregnancies and a neonatal intensive care unit (NICU) was offered.

The study was approved by the Institutional Ethics Committee (date: 15/10/2019; project no.: KA19/331).

\section{Statistical Analysis}

Statistical analysis was performed using the SPSS statistical package (Version 17.0, SPSS Inc., Chicago, IL, USA). Categorical measurements are reported as number and percentage, and continuous measurements are summarized as mean values and standard deviations. Comparisons between groups were performed using Student's t-test for normally distributed data, and the Mann-Whitney U test was used for data that were not normally distributed. The categorical variables between the groups were analyzed using the chi-square test or Fisher's exact test. Values of $p<0.05$ were considered statistically significant.

\section{Results}

Seven hundred sixty-nine patients were diagnosed as having ectopic pregnancies between December 2012 and July 2019, 53 of whom had CSPs; the incidence rate among all ectopic pregnancies was $6.8 \%$. Two of the 53 patients declined treatment and left the center, and three patients desired to continue the pregnancy despite all the explained risks. As a result, the treatment outcomes of 48 out of 53 patients were available for the final analysis (Figure 1).

The mean age of the study group was 33.7 (range, 23-43 years). The mean numbers of gestations and previous cesarean deliveries were 3.5 and 1.6, respectively. The general clinical features of the study group are summarized in Table 1.

The mean gestational week at the time of diagnosis was 6.3 weeks, the mean gestational sac diameter was 15 (range, 6-50)

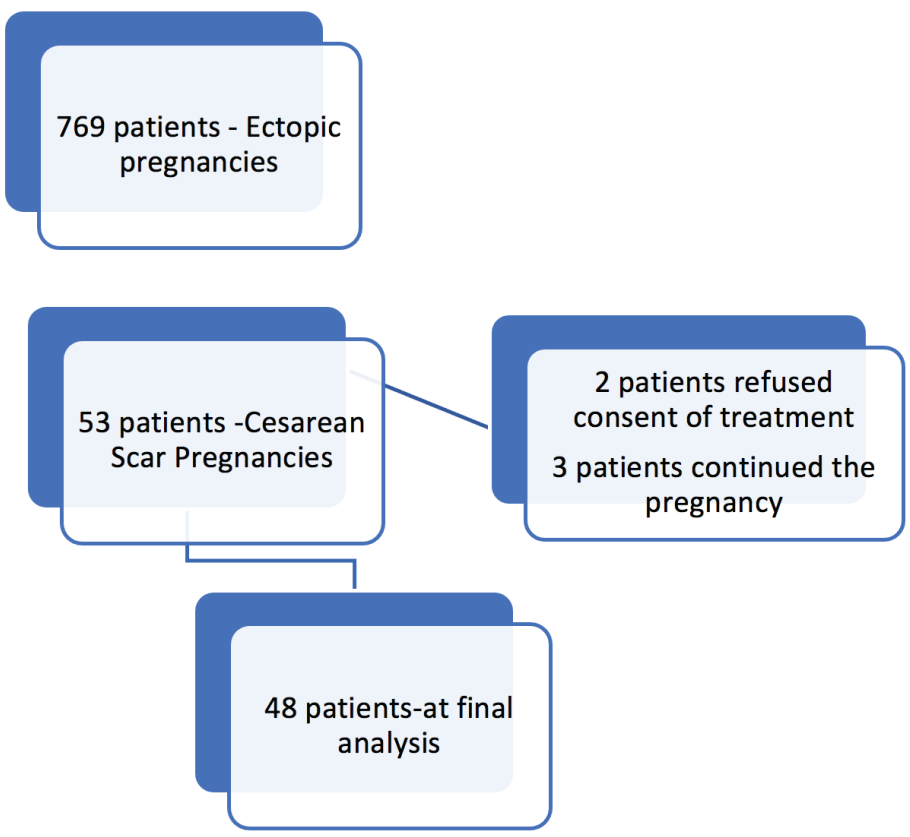

Figure 1. Flow diagram of the study

$\mathrm{mm}$, and the mean beta-hCG level at the time of diagnosis was $48.106 \mathrm{mIU} / \mathrm{mL}$. All diagnoses were made using transvaginal USG imaging. The features of CSP are shown in Table 2.

There were five, nine, and four patients in the systemic methotrexate, local methotrexate, and combined approach groups, respectively. Hysteroscopic resection was performed in eight patients, 19 patients underwent USG-guided D\&E, and laparotomic and laparoscopic resection of CSP was performed for one and two patients, respectively. These treatment modalities were for the surgical approach group.

The age and number of gestations and previous cesarean deliveries were similar between the medical and surgical approach groups ( $\mathrm{p}=0.11, \mathrm{p}=0.25, \mathrm{p}=0.14$, respectively). The success rate of the medical treatment group and the surgical group was $33.3 \%$ and $96.6 \%$, respectively, the difference was found to be statistically significant $(\mathrm{p}<0.001)$ (Table 3$)$. The complication rates for the medical and surgical approaches were $66.6 \%$ and $3.3 \%$, respectively. The complication rate of medical treatment was significantly higher than for surgical methods $(\mathrm{p}<0.001)$. The treatment outcome of each treatment modality is shown in Table 4 and 5 . The most frequent complication of the entire study group was treatment failure and the need for second-line treatment.

The mean interval to a negative beta-hCG was determined as 28 days. The decrement of beta-hCG levels is shown in figure 2. Although the mean interval to a negative beta-hCG in the surgically managed group was shorter by 10 days (mean 18 days), beta-hCG levels were not monitored postoperatively in most patients in the surgical group due to the complete removal of CSP material. 
Table 1. Clinical characteristics of the patients

\begin{tabular}{|c|c|c|c|}
\hline & Mean & $\begin{array}{l}\text { Number } \\
\text { of } \\
\text { patients }\end{array}$ & $\%$ \\
\hline $\begin{array}{l}\text { Age at } \\
\text { diagnosis } \\
\text { (years) }\end{array}$ & $33.7(23-43)$ & 52 n/a: 1 & \\
\hline Gravida & $3.5(2-8)$ & 52 n/a: 1 & \\
\hline Parity & $1.6(1-3)$ & $52 \mathrm{n} / \mathrm{a}: 1$ & \\
\hline $\begin{array}{l}\text { Gestational } \\
\text { week at last } \\
\text { delivery } \\
\text { (weeks) }\end{array}$ & $37.9(30-41)$ & 47 n/a: 6 & \\
\hline $\begin{array}{l}\text { Number of } \\
\text { previous C/S } \\
\text { deliveries }\end{array}$ & $\begin{array}{l}1 \\
2 \\
3\end{array}$ & $\begin{array}{l}23 \\
25 \\
4 \\
52 \\
\text { n/a: } 1\end{array}$ & $\begin{array}{l}43.4 \% \\
47.2 \% \\
7.5 \%\end{array}$ \\
\hline $\begin{array}{l}\text { Indications } \\
\text { of last } \mathrm{C} / \mathrm{S} \\
\text { delivery }\end{array}$ & $\begin{array}{l}\text { Previous C/S } \\
\text { Obstructed delivery } \\
\text { Maternal request } \\
\text { Fetal distress } \\
\text { Presentation anomalies } \\
\text { Multiple pregnancies } \\
\text { Cephalopelvic Disproportion } \\
\text { Placenta previa }\end{array}$ & $\begin{array}{l}26 \\
2 \\
9 \\
7 \\
1 \\
1 \\
1 \\
1 \\
\text { n/a: } 5\end{array}$ & $\begin{array}{l}49.1 \% \\
3.8 \% \\
17 \% \\
13.2 \% \\
1.9 \% \\
1.9 \% \\
1.9 \% \\
1.9 \%\end{array}$ \\
\hline $\begin{array}{l}\text { History of } \\
\text { additional } \\
\text { uterine } \\
\text { surgery }\end{array}$ & $\begin{array}{l}\text { None } \\
\text { D\&C } \\
\text { H/S polyp resection } \\
\text { D\&C+Surgical H/S }\end{array}$ & $\begin{array}{l}25 \\
24 \\
2 \\
1 \\
\text { n/a: } 1\end{array}$ & $\begin{array}{l}47.2 \% \\
45.3 \% \\
3.8 \% \\
1.9 \%\end{array}$ \\
\hline $\begin{array}{l}\text { Ectopic } \\
\text { pregnancy } \\
\text { history }\end{array}$ & $\begin{array}{l}\text { None } \\
\text { Tubal } \\
\text { Cesarean scar }\end{array}$ & $\begin{array}{l}50 \\
1 \\
1 \\
\text { n/a: } 1\end{array}$ & $\begin{array}{l}94.3 \% \\
1.9 \% \\
1.9 \%\end{array}$ \\
\hline $\begin{array}{l}\text { Time after last } \\
\text { delivery }\end{array}$ & 5.6 (range, $1-13$ ) years & & \\
\hline
\end{tabular}

Three patients preferred to continue their pregnancies after being informed about the potential risks. During the follow-up of these three patients, placental adherence abnormalities were detected. One patient presented to the emergency department at the $32^{\text {nd }}$ gestational week with symptoms of lower abdominal pain and preterm birth was diagnosed. Bilateral hypogastric artery ligation was performed due to severe intrapartum hemorrhage, but this procedure failed and hysterectomy was performed. Bladder injuries occurred in several areas and were repaired primarily; four units of red blood cell transfusion were needed. The newborn was followed in the NICU for 10 days and was given phototherapy for hyperbilirubinemia. The second patient was admitted to the emergency department with
Table 2. Characteristics of cesarean scar pregnancies

\begin{tabular}{|c|c|c|c|}
\hline & & $\begin{array}{l}\text { Number } \\
\text { of } \\
\text { patients }\end{array}$ & $\%$ \\
\hline Pregnancy type & $\begin{array}{l}\text { Spontaneous } \\
\text { ART }\end{array}$ & $\begin{array}{l}47 \\
2 \\
\text { n/a: } 4\end{array}$ & $\begin{array}{l}88.7 \% \\
3.8 \%\end{array}$ \\
\hline $\begin{array}{l}\text { Gestational week at the } \\
\text { time of diagnosis }\end{array}$ & $\begin{array}{l}\text { Mean: } 6.3 \text { (range, } \\
5-10 \text { ) }\end{array}$ & & \\
\hline Number of fetuses & $\begin{array}{l}\text { Singleton } \\
\text { Twin }\end{array}$ & $\begin{array}{l}51 \\
1 \\
\text { n/a: } 1\end{array}$ & $96.2 \%$ \\
\hline $\begin{array}{l}\text { Fetal cardiac activity at } \\
\text { the time of diagnosis }\end{array}$ & $\begin{array}{l}(+) \\
(-)\end{array}$ & $\begin{array}{l}14 \\
35 \\
\text { n/a: } 4\end{array}$ & $\begin{array}{l}26.4 \% \\
66 \%\end{array}$ \\
\hline $\begin{array}{l}\text { Imaging modality used } \\
\text { for diagnosis }\end{array}$ & TVUSG & 53 & $100 \%$ \\
\hline Symptoms & $\begin{array}{l}\text { Asymptomatic } \\
\text { Vaginal Bleeding } \\
\text { Irregular bleeding } \\
\text { Abdominal Pain }\end{array}$ & $\begin{array}{l}33 \\
13 \\
1 \\
3 \\
\text { n/a: } 3\end{array}$ & $\begin{array}{l}62.3 \% \\
24.5 \% \\
1.9 \% \\
5.7 \%\end{array}$ \\
\hline
\end{tabular}

Table 3. Comparison of success and complication rates of medical versus surgical treatment modalities

\begin{tabular}{|c|c|c|c|}
\hline & $\begin{array}{l}\text { Medical } \\
\text { treatment }\end{array}$ & $\begin{array}{l}\text { Surgical } \\
\text { Treatment }\end{array}$ & $\mathrm{p}$ \\
\hline Complication rate & $\mathrm{n}=12(66 \%)^{*}$ & $\mathrm{n}=1(3.3 \%) \dagger$ & $<0.001$ \\
\hline Success of treatment & $\mathrm{n}=6(33.3 \%)$ & $\mathrm{n}=29(96.6 \%)$ & $<0.001$ \\
\hline
\end{tabular}

symptoms of vaginal bleeding. After the bleeding worsened at the $35^{\text {th }}$ gestational week, an emergency cesarean section was performed. Intrapartum heavy bleeding led to a hysterectomy. The newborn of this patient had respiratory insufficiency and died in the NICU. The last patient's delivery occurred in another center. A telephone interview revealed that the patient had severe intrapartum bleeding and was managed by hysterectomy and a massive transfusion was needed.

Forty-five of the 53 patients' follow-up data were obtained. In total, 20 pregnancies were detected subsequently, 19 of which were spontaneous, and none were in vitro fertilization pregnancies. Two patients had another CSP (10\% of subsequent pregnancies). Fifteen patients gave birth, and five aborted. One patient had cervical insufficiency in her subsequent pregnancy and one had preterm premature rupture of membranes.

\section{Discussion}

One of the main results of our study was that the surgical approach was found to be more effective in the treatment of 
Table 4. Complication rate and types according to treatment modality

\begin{tabular}{|c|c|c|c|}
\hline & $\begin{array}{l}\text { Complication } \\
(+)\end{array}$ & $\begin{array}{l}\text { Complication } \\
(-)\end{array}$ & $\begin{array}{l}\text { Types of } \\
\text { complication }\end{array}$ \\
\hline $\begin{array}{l}\text { Systemic } \\
\text { methotrexate }\end{array}$ & $2(40 \%)$ & $3(60 \%)$ & $\begin{array}{l}\text { Persistance of } \\
\text { scar pregnancy } \\
(\mathrm{n}=2)\end{array}$ \\
\hline $\begin{array}{l}\text { Local } \\
\text { methotrexate } \\
\text { and GS } \\
\text { aspiration }\end{array}$ & $7(77 \%)$ & $2(22 \%)$ & $\begin{array}{l}\text { Massive } \\
\text { bleeding }(\mathrm{n}=2) \\
\text { Intrauterine } \\
\text { infection }(\mathrm{n}=1) \\
\text { Persistance of } \\
\text { scar pregnancy } \\
(\mathrm{n}=4)\end{array}$ \\
\hline $\begin{array}{l}\text { Combined } \\
\text { methotrexate* }\end{array}$ & $3(75 \%)$ & $1(25 \%)$ & $\begin{array}{l}\text { Massive } \\
\text { bleeding }(\mathrm{n}=1) \\
\text { Persistance of } \\
\text { scar pregnancy } \\
(\mathrm{n}=1) \\
\text { Persistance of } \\
\text { ectopic mass } \\
(\mathrm{n}=1)\end{array}$ \\
\hline $\begin{array}{l}\text { Hysteroscopic } \\
\text { resection }\end{array}$ & 0 & $8(100 \%)$ & \\
\hline $\mathrm{D} \& \mathrm{E}$ & $1(5.3)$ & $18(94.7)$ & $\begin{array}{l}\text { Persistance of } \\
\text { ectopic mass } \\
(n=1)\end{array}$ \\
\hline $\begin{array}{l}\text { Laparoscopic } \\
\text { resection }\end{array}$ & 0 & $1(100 \%)$ & \\
\hline $\begin{array}{l}\text { Laparotomic } \\
\text { resection }\end{array}$ & 0 & $2(100 \%)$ & \\
\hline Total & 13 & 35 & \\
\hline
\end{tabular}

D\&E: Dilatation-evacuation

Table 5. The success rate of treatment modalities

\begin{tabular}{l|l|l|}
\hline & $\begin{array}{l}\text { Success rate of } \\
\text { treatments }\end{array}$ & $\begin{array}{l}\text { Number of } \\
\text { patients }\end{array}$ \\
\hline $\begin{array}{l}\text { Systemic methotrexate } \\
\begin{array}{l}\text { Local methotrexate and GS } \\
\text { aspiration }\end{array}\end{array}$ & $\mathrm{n}=3(60 \%)$ & $\mathrm{n}=5$ \\
\hline $\begin{array}{l}\text { Combined methotrexated } \\
\text { Hysteroscopic resection }\end{array}$ & $\mathrm{n}=1(25 \%)$ & $\mathrm{n}=9$ \\
\hline D\&E & $\mathrm{n}=8(100 \%)$ & $\mathrm{n}=4$ \\
\hline Laparoscopic resection & $\mathrm{n}=18(94.7 \%)$ & $\mathrm{n}=19$ \\
\hline Laparotomic resection & $\mathrm{n}=1(100 \%)$ & $\mathrm{n}=1$ \\
\hline Total & $\mathrm{n}=2(100 \%)$ & $\mathrm{n}=2$ \\
\hline D\&E: Dilatation-evacuation & & 48
\end{tabular}

CSP with lower complication rates compared with the medical approach. Also, we observed that the risks of placental adhesion abnormalities and severe postpartum hemorrhage were quite high with the continuation of viable CSPs.

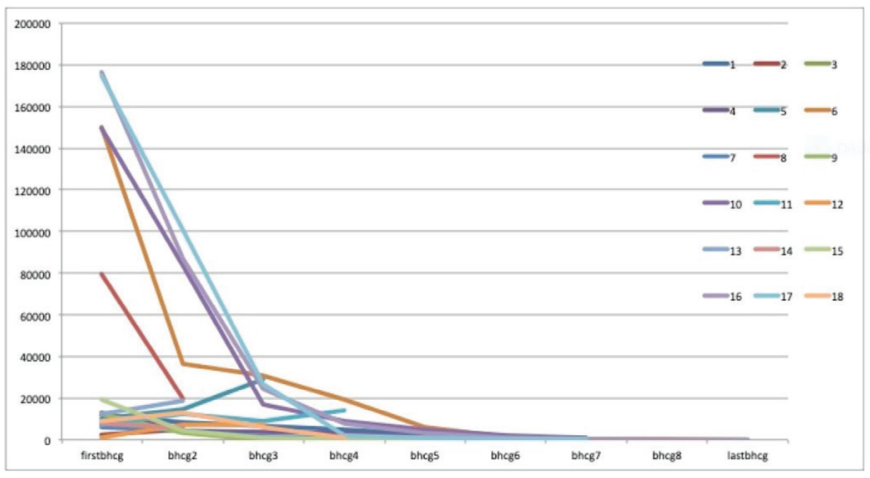

Figure 2. Decrement of beta-hCG levels in the medically treated group

Although there were limited cases until the early 2000s, the incidence rate of scar pregnancies has risen and now accounts for almost $6 \%$ of all ectopic pregnancies ${ }^{(9)}$. In this study, we also found the rate of scar pregnancies among all ectopic pregnancies as $6.8 \%$. There are more than 30 approaches described in the literature, and their efficacy has been investigated, mostly in case series. In one series, Timor-Trisch et al. ${ }^{(1)}$ found local methotrexate to be an effective and safe treatment choice. Some studies propose local methotrexate as a first-line treatment ${ }^{(10,11)}$. In another study comprising 24 non-tubal ectopic pregnancies, it was concluded that the conservative approach should be preferred first ${ }^{(12)}$. Although the time to negative beta-hCG is longer, systemic methotrexate treatment was found to be effective in a 26-patient case series, and it could protect patients against more invasive surgical procedures ${ }^{(13)}$.

The need for second-line treatment was found at rates of $8.3 \%, 25 \%$, and $33 \%$, for combined methotrexate, systemic methotrexate, and expectant approaches, respectively, in the case series of Grechukhina et al. ${ }^{(14)}$. A study from the United Kingdom reported the success rates of medical and surgical treatments as $46 \%$ and $96 \%$, respectivel ${ }^{(15)}$.

There is no standardized treatment protocol for CSP because it is a relatively rare clinical condition and studies have contradictory outcomes. A systematic review including 52 studies concluded that local, systemic, and combined methotrexate treatments should not be used as first-line treatment because of high failure and complication rates ${ }^{(16)}$. In the present study, the success and complication rates were $33.3 \%$ and $66.6 \%$ for the medical approach and $96.6 \%$ and $3.3 \%$ for surgical approaches, respectively. The results of our study favor surgical approaches as the first-line treatment, supporting the results of the systematic review of Birch et al. ${ }^{(16)}$.

Kim et al. ${ }^{(17)}$ reported that the risk of massive hemorrhage and emergency hysterectomy was higher in patients managed with dilation and curettage ( $D \& C$ ), even if it was performed under USG guidance. The complication rate of D\&C was found to be about $20 \%$ in a systematic review, and the authors recommended not to use $D \& C$ as the first-line treatment because of the high complication rates ${ }^{(16)}$. Contrary to the literature, in our study, 
we found that D\&E was successful as a first-line approach for 94\% of patients (18 out of 19 patients); only one patient needed second-line treatment because of a persistent mass in the scar area even though the beta-hCG level was negative, and this patient was successfully managed with operative hysteroscopy. The main reason for our lower complication rates might be the avoidance of sharp curettage in most cases and evacuation with suction cannula as described under the "material and method topic".

Potential parameters to predict the efficacy of various management strategies were investigated by some authors. Less invasive medical approaches were found to be appropriate for patients with low beta-hCG levels, type 1 CSP, and small gestational sac diameter at the time of diagnosis ${ }^{(18)}$. Surgical treatment modalities were recommended as the first-line approach in patients with large gestational sac diameters and increased trophoblastic charge ${ }^{(19)}$. In a prospective observational study of Sun et al. ${ }^{(20)}$, a risk stratification model was established that took the number of previous cesarean deliveries, residual myometrial thickness, gestational sac diameter, fetal cardiac activity, and Doppler USG findings into account. Evacuation was recommended for the low-risk group, uterine artery embolization for the intermediate-risk group, and laparoscopic resection was recommended for patients at high-risk.

Age, gravidity, parity, and previous cesarean deliveries were similar between the medically and surgically managed patients in this study. The mean beta-hCG levels at the time of diagnosis were $12.423 \mathrm{mIU} / \mathrm{mL}$ and $14.799 \mathrm{mIU} / \mathrm{mL}$ for medically and surgically treated patients, respectively $(\mathrm{p}=0.8)$. A comparison regarding gestational sac diameter could not be made because diameter information was not available in most patients' records. Persistent mass at the scar area was the only complication in the surgically managed group. Our preferential surgical approach was D\&E without sharp curettage in 19/30 patients and hysteroscopy in $8 / 30$ cases. No patients needed an emergency hysterectomy in the surgery group. The low complication and failure rates are advantages when we take the young age and fertility desire of these patients into account. Although most of the complications were treatment failure and the need for a second-line approach, three patients had severe, lifethreatening hemorrhage in the medically managed group. Massive transfusion was needed for two of these patients. The absence of life-threatening complications in surgically managed patients suggests that these modalities are safe. However, this must be evaluated with caution because these procedures were performed by experienced surgeons in a tertiary setting. It should not be forgotten that there may be a need for emergency hysterectomy in both medically and surgically managed patients. Another advantage of surgical procedures was the shorter mean interval for a negative beta-hCG level, which was 18 and 28 days for the medical and surgical groups, respectively.

Although most authors recommend the termination of viable CSPs, some patients may choose to continue their pregnancy.
CSP and placenta accreta share the same histopathologic characteristics ${ }^{(21)}$. Cali et al. ${ }^{(22)}$ reported a rate of $75 \%$ for placental adhesion abnormalities in their expectantly managed group and stated that two-thirds of the patients had placenta percreta in their meta-analysis. Three patients who chose to continue their pregnancies in this case series also had placenta percreta, and all of them needed postpartum hysterectomy against intractable life-threatening hemorrhage. The risk of placental adhesion abnormalities and the risk of severe hemorrhage should be highlighted for patients who have positive fetal cardiac activity and desire continuation of pregnancy.

There are limited data on future fertility after CSPs in the literature. In one study, four out of 10 pregnancies that occurred after CSP treatment were also scar pregnancies (Grechukhina et al. $\left.{ }^{(14)}, 2018\right)$ Although most patients can conceive spontaneously after a scar pregnancy, the risks of recurrence and placental adhesion abnormalities increase ${ }^{(23)}$. In our patient group, 20 pregnancies occurred after scar pregnancies, five (25\%) of which resulted in spontaneous abortions and two (10\%) were recurrent CSPs.

\section{Study Limitations}

The main limitation of this study arises from its retrospective nature. Objective discrimination of CSP type was not available. Not every treatment approach described in the literature was performed in this case series. For example, no patients were managed with uterine artery embolization; therefore, no comment or comparison could be made regarding these modalities. On the other hand, this study was conducted in a tertiary center that was representative of its region, and the size of the patient group was satisfactory when given the rarity of this clinical entity.

\section{Conclusion}

The results of this study support surgical approaches due to their success and safety. Besides having fewer failures and lower complication rates, the shorter interval to negative beta-hCG is another advantage of surgical treatment. However, the results should be interpreted cautiously because this study is also a retrospective case series of a tertiary referral center. Randomized prospective studies are needed for an objective categorization of the relationship of conceptus and the endometrial cavity to better determine the most appropriate treatment. Risk stratification studies may be useful in this context. No comment could be made in this study regarding the prediction of appropriate individualized treatment choices; surgical treatment seems more effective than medical modalities. The decision for continuation of pregnancy in the event of positive fetal cardiac activity is extremely risky; placental adhesion abnormalities are almost always detected in such cases and severe postpartum hemorrhage and hysterectomy risks should be highlighted for patients. 


\section{Ethics}

Ethics Committee Approval: The study was approved by the Institutional Ethics Committee (date: 15/10/2019; project no.: KA19/331)

Informed Consent: Informed consent forms were signed by all patients.

Peer-review: Externally peer-reviewed.

\section{Authorship Contributions}

Concept: S.Y.S.., T.Ç., Design: S.Y.Ş., Data Collection or Processing: D.A.Y., S.Y.B., T.C.., E.B.K., Analysis or Interpretation: E.S., D.A.Y., S.Y.B., Literature Search: T.Ç., E.B.K., Writing: S.Y.Ş., E.S., E.B.K.

Conflict of Interest: The authors report no conflict of interest. Financial Disclosure: Authors have no financial interests about the research.

\section{References}

1. Timor-Tritsch IE, Monteaguda A, Tsymbal T, Tsymbal T, Pineda G, Arslan AA. The diagnosis, treatment, and follow-up of cesarean scar pregnancy. Am J Obstet Gynecol 2012;207:44.e1-13. doi: 10.1016/j.ajog.2012.04.018.

2. Fylstra DL. Ectopic pregnancy within a cesarean scar: a review. Obstet Gynecol Surv 2002;57:537-43.

3. Marchiolé P, Garlore F, de Caro G, Podestà M, Valenzano M. Intramural pregnancy embedded in a previous Cesarean section scar treated conservatively. Ultrasound Obstet Gynecol 2004;23:307-9.

4. Seow KM, Huang L-W, Lin Y-H, Yan-Sheng Lin M, Tsai Y-L, Hwang J-L. Cesarean scar pregnancy: issues in management' Ultrasound Obstet Gynecol 2004;23:247-53.

5. Jurkovic D, Hillaby K, Woelfer B, Lawrence A, Salim R, Elson CJ. First-trimester diagnosis and management of pregnancies implanted into the lower uterine segment Cesarean section scar. Ultrasound Obstet Gynecol 2003;21:220-7.

6. Gonzalez N, Tulandi T. Cesarean scar pregnancy: a systematic review. J Minim Invasive Gynecol 2017;24:731-8.

7. Vial Y, Petignat P, Hohlfeld P. Pregnancy in a cesarean scar. Ultrasound Obstet Gynecol 2000;16:592-3.

8. Shi M, Zhang H, Qi S-S, Liu W-H, Liu M, Zhao X-B, et al. Identifying risk factors for cesarean scar pregnancy: a retrospective study of 79 cases. Ginekol Pol 2018;89:195-9.

9. Parker VL, Srinivas M. Non-tubal ectopic pregnancy. Arch Gynecol Obstet 2016;294:19-27.

10. Cok T, Kalayci H, Ozdemir H, Haydardedeoglu B, Parlakgumus AH, Tarim E. Transvaginal ultrasound-guided local methotrexate administration as the first-line treatment for cesarean scar pregnancy: Follow-up of 18 cases. J Obstet Gynaecol Res 2015;41:803-8.
11. Naeh A, Shrim A, Shdam-Paz E, Amir M, Hallak M, Bruchim I. Cesarean scar pregnancy managed with local and systemic methotrexate: a single center case series. Eur J Obstet Gynecol Reprod Biol 2019;238:138-42.

12. Jachymski T, Moczulska H, Guzowski G, Pomorski M, Piątek S, Zimmer $\mathrm{M}$, et al. Conservative treatment of abnormally located intrauterine pregnancies (cervical and cesarean scar pregnancies): a multicenter analysis (Polish series). J Matern Fetal Neonatal Med 2020;33:993-8

13. Jabeen K, Karuppaswamy J. Non-surgical management of cesarean scar ectopic pregnancy-a five-year experience. J Obstet Gynaecol 2018;38:1121-7.

14. Grechukhina O, Deshmukh U, Fan L, Kohari K, Abdel-Razeq $\mathrm{S}$, Bahtiyar $\mathrm{MO}$, et al. Cesarean scar pregnancy, incidence, and recurrence: five-year experience at a single tertiary care referral center. Obstet Gynecol 2018;132:1285-95.

15. Harb HM, Knight M, Bottomley C, Overton C, Tobias A, Gallos ID, et al. Cesarean scar pregnancy in the UK: a national cohort study. BJOG 2018; 125:1663-70.

16. Birch PK, Hoffman E, Larsen CR, Nielsen HS. Cesarean scar pregnancy: a systematic review of treatment studies. Fertil Steril 2016;105:958-67.

17. Kim SY, Yoon SR, Kim MJ, Chung JH, Kim MY, Lee SW. Cesarean scar pregnancy; cesarean scar pregnancy: a systematic review of treatment studies. Taiwan J Obstet Gynecol 2018;57:688-91.

18. Tahaoglu AE, Dogan Y, Bakir M, Baglı I, Peker N, Cavus Y, et al. A single centre's experience of cesarean scar pregnancy and proposal of a management algorithm. J Obstet Gynaecol 2019;39:259-64.

19. Dior UP, Palma-Dias R, Reidy K, Cheng C, Healey M. Cesarean scar pregnancies: incidence and factors associated with conversion to surgery from medical management. J Minim Invasive Gynecol 2019;26:919-27.

20. Sun QL, Luo L, Gao CY, Yan P, Yang Y, Chen Z-Q. Scoring system for the prediction of the successful treatment modality in women with cesarean scar pregnancy. Int J Gynecol Obstet 2019;146:28995.

21. Timor-Tritsch IE, Monteagudo A, Cali G, Palacios-Jaraquemada JM, Maymon R, Arslan AA, et al. Cesarean scar pregnancy and early placenta accreta share common histology. Ultrasound Obstet Gynecol 2014:43:3083-95.

22. Calì G, Timor-Tritsch IE, Palacios-Jaraquemada J, Monteaugudo A, Buca D, F Forlani F, et al. Outcome of Cesarean scar pregnancy managed expectantly: systematic review and meta-analysis. Ultrasound Obstet Gynecol 2018:169-75.

23. Gao L, Huang Z, Zhang X, Zhou N, Huang X, Wang X. Reproductive outcomes following cesarean scar pregnancy - a case series and review of the literature. Eur J Obstet Gynecol Reprod Biol 2016;200:102-7. 